\title{
PERANCANGAN MODEL STRUKTURAL HUBUNGAN ATRIBUT INDIVIDU DAN KESIAPAN BERUBAH - STUDI KUALITATIF MENGGUNAKAN SENSEMAKING
}

\author{
Eva Hotnaidah Saragih \\ Program Doktor Bisnis dan Manajemen \\ Institut Pertanian Bogor \\ Parulian Hutagaol \\ Institut Pertanian Bogor \\ Bomer Pasaribu \\ Institut Pertanian Bogor \\ Setiadi Djohar \\ Institut Pertanian Bogor
}

\begin{abstract}
Dalam lima tahun terakhir, terdapat tiga perusahaan televisi swasta nasional di Indonesia yang berhasil melakukan perubahan transformasional di tingkat korporat. Secara teori, implementasi perubahan pada organisasi semacam ini akan sulit dilakukan karena tingkat resistensi tidak sama dengan nol (Ansoff\&McDonnell, 1990). Resisting Change merupakan salah satu dimensi dari kesiapan berubah yang bersifat negatif. Dua dimensi lainnya yang bersifat positif adalah Participating and Promoting Change (Hanpachern, Morgan \& Griego, 1998). Holt et al (2007) mengkategorikan anteseden kesiapan berubah dalam empat perspektif: content, context, process, dan individual attributes. Dari keempat perspektif tersebut, faktor kunci kesiapan organisasi untuk berubah terletak pada faktor atribut individu yaitu karakteristik dari sumber daya manusia. Penelitian ini merupakan studi eksplorasi yang bertujuan mengetahui atribut individu apa yang dimiliki dan memampukan karyawan di tiga perusahaan tersebut siap menghadapi dan sukses mengimplementasikan perubahan. Apakah temuan sama dengan hasil penelitian sebelumnya di negeri barat yaitu efficacy dan leadership, atau ditemukan adanya atribut individu lainnya. Penelitian ini merupakan bagian pertama dari dua tahapan studi yang dilakukan secara terpisah. Pada penelitian tahap pertama yang bersifat kualitatif ini dilakukan wawancara individual secara mendalam terhadap narasumber pelaku utama perubahan pada tiga perusahaan televisi yang menjadi obyek studi. Data diolah dan dianalisis menggunakan sense-making melalui analisis baris. Hasil penelitian berhasil mengidentifikasi 15 atribut individu yang kemudian dikelompokkan menjadi empat kategori, yaitu: Psychological Capital, Transformational Leadership Behavior, Way of Thinking dan Organizational Commiment. Atribut individu yang muncul dikemukakan oleh seluruh narasumber adalah Efficacy, Resiliency, Optimism, Inspiring a Shared Vision, Enabling Others to Act, Modeling The Way, Rational Thinking dan Affective Commitment. Modeling the Way dtemukan sebagai atribut individu yang paling sering dikemukakan oleh seluruh narasumber, diikuti Affective Commitment, Enabling Others to Act dan Resiliency.
\end{abstract}

Keywords:

psychological capital, transformational leadership behavior, way of thinking, organizational commitment, change readiness, sense-making 


\section{PENDAHULUAN}

Dalam usaha memenangkan persaingan bisnis, pada kurun waktu sekitar lima tahun terakhir, terdapat tiga perusahaan televisi swasta nasional di Indonesia yang melakukan perubahan transformasional tingkat korporat. Mengacu pada teori Ansoff \& McDonnell (1990), tingkat resistensi terhadap perubahan pada organisasi seperti ini tidak sama dengan nol, sehingga inisiatif perubahan tidak mudah untuk diimplementasikan. Tetapi pengalaman perubahan di ketiga perusahaan televisi tersebut menunjukkan hasil berbeda. Perubahan berhasil diimplementasikan, kinerja perusahaan meningkat dan ketiganya saat ini berhasil menempatkan diri sebagai televisi terkemuka yang berpengaruh di Indonesia (INDOCOMMERCIAL， 2011; Rahayu, 2010; Mulya, 2011).

Dari hasil telaah literatur baik teori dan hasil penelitian sebelumnya, hampir sebagian besar ahli perilaku organisasi sepakat bahwa faktor manusia merupakan anteseden yang paling mungkin dari keberhasilan atau ketidakberhasilan suatu inisiatif perubahan (Armenakis, Harris dan Mossholder, 1993; Eby et al, 2000; Cunningham et al, 2002). Palmer, Dunford \& Akin (2009) mengemukakan, tanpa kesiapan berubah dari individu pelaku perubahan maka tidak terdapat hubungan antara strategi manajemen perubahan dengan outcomes strategi tersebut. Menurut Hanpachern, Morgan \& Griego (1998), kesiapan berubah memiliki tiga dimensi, yaitu: resisting, promoting dan participating. Resistensi merupakan dimensi negatif dari kesiapan berubah. Semakin tinggi resistensi terhadap perubahan, semakin rendah kesiapan individu dan organisasi untuk berubah. Sedangkan promosi dan partisipasi merupakan dimensi positif dari kesiapan berubah. Semakin tinggi tingkat promosi dan partisipasi terhadap perubahan, semakin tinggi kesiapan individu dan organisasi untuk berubah (Rafferty \& Simons, 2006). Holt et al (2007) mengkategorikan anteseden kesiapan berubah dalam empat perspektif: atribut dari inisiatif perubahan yang akan diimplementasikan (content), atribut dari kondisi dan lingkungan dimana insiatif perubahan diimplementasikan (context), atribut dari langkah-langkah yang diambil untuk mengimplementasikan inisiatif perubahan (process), dan atribut atau karakteristik dari sumber daya manusia yang diminta untuk mengimplementasikan inisiatif perubahan yang ditetapkan (individual attributes). Gambar 1. menunjukkan kerangka pikir berdasarkan hasil telaah literatur.

Dari keempat perspektif tersebut, faktor kunci kesiapan organisasi untuk berubah terletak pada faktor atribut individu yaitu karakteristik dari sumber daya manusia. Bila individu tidak meyakini perlunya perubahan, atau tidak yakin organisasi mampu melakukan perubahan, maka inisiatif perubahan yang direncanakan sebaik apapun tidak akan terlaksana (Armenakis et al, 1993; Cunningham et al, 2002; Eby et al, 2000; Smith, 2005).

Di Indonesia, belum ditemukan penelitian terkait perspektif atribut individu dari kesiapan berubah pada bidang manajemen bisnis. Di luar Indonesia, walaupun dalam sepuluh hingga lima belas tahun terakhir sudah dilakukan beberapa penelitian terkait kesiapan berubah di bidang perilaku organisasi yang menemukan adanya sejumlah faktor individu, kelompok maupun organisasi yang berkontribusi terhadap kesiapan berubah, namun sebagian besar variabel tersebut dieksplorasi baru pada sejumlah kecil penelitian. Penelitian terkait yang dilakukan baru menemukan faktor efficacy (Armenakis et al, 1993; Cunningham et al, 2002; Smith, 2005; 
Raffery \& Simons, 2006; Holt et al, 2007; Self \& Schraeder, 2009) dan leadership (Smith, 2005; Grieve, 2005; Rafferty \& Simons, 2006) sebagai anteseden langsung dari kesiapan berubah. Diduga masih banyak faktor karakteristik sumber daya manusia lainnya yang mungkin berpengaruh secara langsung maupun tidak langsung, yang belum terinvestigasi (Madsen et al, 2005).

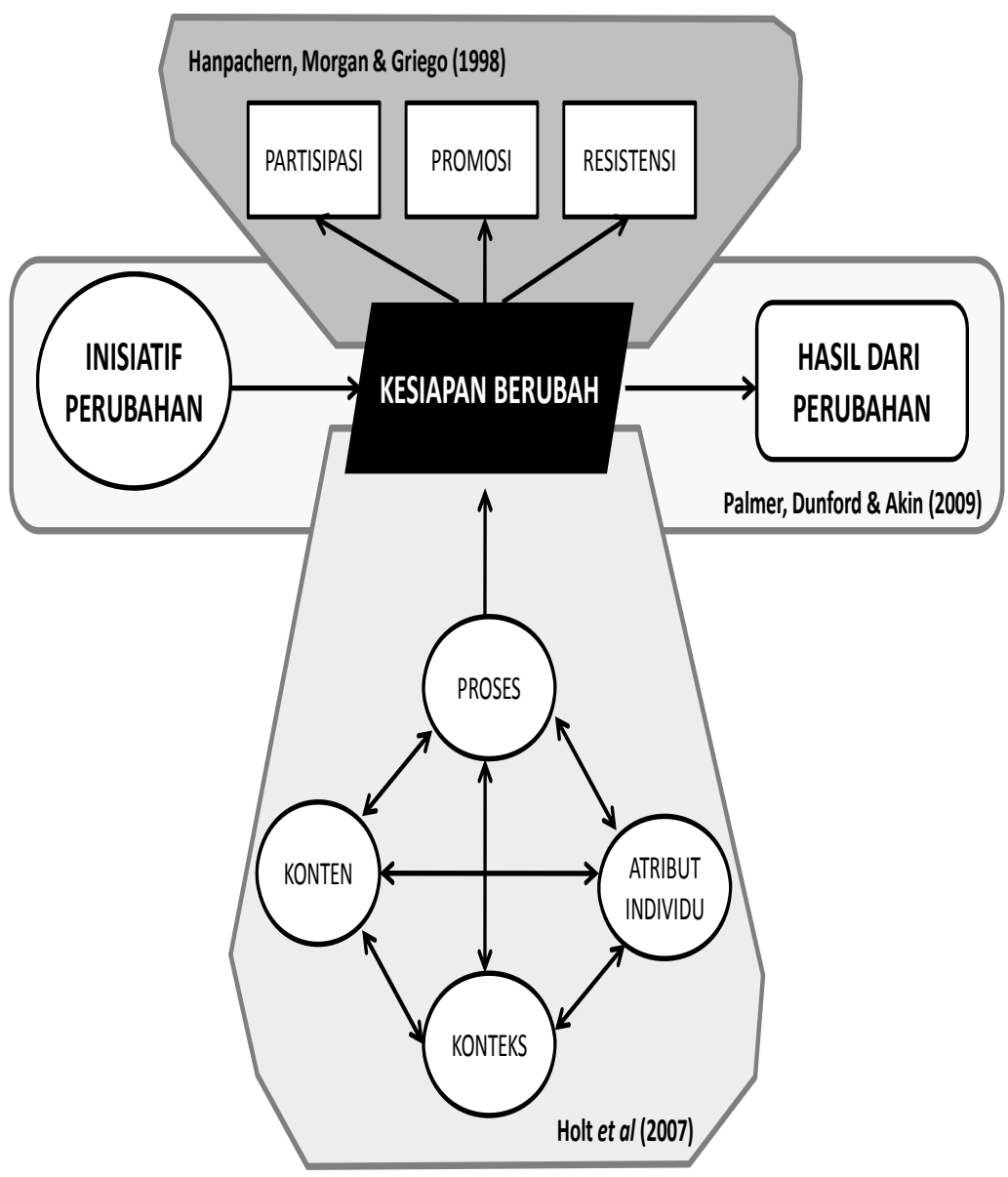

Gambar 1.

Kerangka Pikir Berdasarkan Hasil Telaah Literatur.

Penelitian ini dilakukan dengan tujuan mendapatkan pembelajaran dari pengalaman sukses ketiga perusahaan televisi tersebut, yang mencakup: (1) Apa saja atribut individu yang dimiliki karyawan dari ketiga televisi tersebut pada saat perubahan diimplementasikan; (2) Apakah atribut individu yang ditemukan sama seperti hasil penelitian sebelumnya di negara barat yaitu efficacy dan leadership, atau ada atribut individu lainnya yang dipandang sebagai faktor karakteristik sumberdaya manusia yang memampukan ketiga televisi tersebut sukses melakukan perubahan 
transformasional di tingkat korporat; (3) Dari sekian banyak atribut individu yang berhasil diidentifikasi, mana yang secara kualitatif dominan muncul sebagai faktor yang memiliki korelasi dengan kesiapan berubah; (4) Bagaimana rancangan model hubungan antara atribut individu dan kesiapan berubah pada industri televisi di Indonesia yang mengalami perubahan transformasional korporat.

\section{METODOLOGI PENELITIAN}

Penelitian dilakukan secara kualitatif melalui studi eksploratori, yang dilakukan karena topik masih baru dan belum pernah diteliti di industri media televisi pada konteks situasi di Indonesia. Studi ini bertujuan menginvestigasi variabel-variabel penting yang selanjutnya akan diuji melalui studi konfirmatori. Tiga perusahaan televisi swasta nasional di Indonesia yang menjadi obyek studi dipilih secara purposive nonprobability sampling berdasarkan kriteria telah mengalami dan berhasil mengimplementasikan inisiatif perubahan transformasional di tingkat korporat dalam kurun waktu lima tahun terakhir. Populasi penelitian adalah seluruh karyawan di tiga perusahaan televisi yang menjadi obyek studi, dengan individu karyawan sebagai unit analisis penelitian.

Pengambilan data dilakukan melalui wawancara individual secara mendalam menggunakan panduan terhadap empat orang narasumber pelaku perubahan dari tiga televisi swasta nasional di Indonesia yang menjadi obyek studi dan satu orang narasumber ahli. Lampiran 1 memuat pedoman wawancara yang digunakan. Sampel atau narasumber wawancara ditetapkan secara purposive-judgment sampling berdasarkan sejumlah kriteria tertentu yang menjadi bahan pertimbangan (Cooper and Schindler, 2008) yaitu memiliki karakteristik yang unik termasuk pengalaman, sikap atau persepsi dikarenakan narasumber adalah pelaku yang terlibat langsung saat inisiatif perubahan diperkenalkan dan proses perubahan dijalankan.

Untuk memahami fenomena strategis proses kompleks pembentukan kesiapan individu untuk berubah dalam manajemen perubahan suatu organisasi, digunakan konsep sensemaking yaitu suatu proses memaknai pernyataan-pernyataan kunci yang dikemukakan narasumber, yang menggambarkan sikap dan perilaku dari narasumber, dengan menggunakan konsep dan teori tertentu sebagai acuan (Weick, 1995). Dari transkrip hasil wawancara, dengan bantuan alat penelitian yang bernama Atlas.ti seri 6.2., dilakukan analisis baris (Goulding, 2002) untuk menemukan kata atau frase kunci yang terkait dengan permasalahan studi. Setelah itu dilakukan kodefikasi terhadap kata kunci hasil identifikasi. Selanjutnya pada studi eksplanatori, hasil kodefikasi dikelompokkan ke dalam beberapa kategori berdasarkan kesamaan sifat dalam menjelaskan suatu perilaku (Scharbo-DeHann, 1993; Goulding, 2002; Louise, 2004). Hasil akhir proses pemaknaan dinyatakan dalam bentuk model penelitian yang akan diuji pada tahap penelitian selanjutnya, yaitu studi konfirmasi secara kuantitatif.

\section{HASIL DAN PEMBAHASAN}

Berdasarkan sense-making melalui analisis baris terhadap transkrip hasil wawancara dengan menggunakan alat penelitian Atlas.ti, didapatkan 346 kutipan pernyataan mengandung kata-kata kunci yang dapat digunakan sebagai dasar mengidentifikasi atribut individu yang terkait dengan kegiatan perubahan di tiga perusahaan televisi swasta nasional di 
Indonesia yang menjadi obyek studi. Dari hasil kodefikasi kata kunci diperoleh 15 atribut individu, yaitu: Hope (HOP), Efficacy (EFF), Resiliency (RES), Optimism (OPT), Challenging the Process (CTP), Inspiring a Shared Vision (ISV), Enabling Others to Act (EOA), Modeling the Way (MTW), Encouraging the Heart (ETH), Presencing (PSC), Rational Thinking (RAT), Intuitive Thinking (INT), Affective Commitment (AFC), Normative Commitment (NOC), dan Continuance Commitment (COC). Lampiran 2 adalah contoh hasil analisis baris untuk salah satu atribut individu hasil identifikasi.

Dengan mengacu pada konsep teori yang dikemukakan Luthans dan Luthans (2010), empat atribut individu yang pertama dikelompokkan menjadi satu kategori yaitu Psychological Capital (PSYCAP). Atribut individu yang pertama dari kategori modal psikologis adalah Hope (Luthans, 2010). Hope didefinisikan sebagai kemauan yang kuat serta cara yang jelas untuk mencapai sasaran. Dari transkrip hasil wawancara didapatkan sebanyak 22 pernyataan sikap dan perilaku yang mencerminkan adanya atribut Hope pada individu karyawan di ketiga perusahaan televisi swasta nasional yang diteliti. Contoh kata kunci yang menggambarkan sikap dan perilaku tersebut adalah: karyawan memahami peran dan inisiatif dalam menjalankan tugas (transkrip 1 baris 35), mengetahui target yang harus dicapai dan berusaha mencapainya (transkrip 3 baris 17 dan 41), memiliki arahan yang jelas dan tahapan/milestone dalam pencapaian sasaran (transkrip 3 baris 37 dan 197), dan mampu mencari cara atasi masalah keterbatasan (transkrip 5 baris 268-269 dan 278).

Atribut individu yang kedua dari kategori modal psikologis adalah Efficacy (Luthans, 2010). Efficacy (confidence to succeed) didefinisikan sebagai keyakinan akan kemampuan seseorang untuk menggerakkan sumberdaya kognitif guna mencapai outcomes tertentu. Efficacy juga berarti adanya keyakinan yang mempengaruhi emosi maupun tindakan bahwa individu memiliki kemampuan untuk melakukan perubahan dan berhasil mengatasi discrepancy (Armenakis et al, 1993; Cunningham et al, 2002; Smith 2005; Rafferty \& Simons, 2006; Holt et al, 2007; Self \& Schraeder, 2009). Dari transkrip hasil wawancara didapatkan sebanyak 13 pernyataan sikap dan perilaku yang mencerminkan adanya atribut Efficacy pada individu karyawan di ketiga perusahaan televisi swasta nasional yang diteliti. Contoh kata kunci yang menggambarkan sikap dan perilaku tersebut adalah: karyawan terbukti berhasil (transkrip 2 baris 101), memiliki sikap "saya/kita bisa" atau "can do attitude" yang tinggi (transkrip 3 baris 41,67 dan 207), semangat dan punya daya saing kuat untuk kalahkan lawan (transkrip 4 baris 61 dan transkrip 5 baris 232-236), berhasil patahkan mindset keliru: news ternyata bisa hasilkan rating dan juga penghasilan yang tinggi (transkrip 4 baris 135), dan berhasil menerima tantangan dari pimpinan dan mengalahkan stasiun televisi lain yang sebelumnya merupakan pemimpin di industri terkait (transkrip 4 baris 191).

Atribut individu yang ketiga dari kategori modal psikologis adalah Resiliency. Resiliency (bouncing back and beyond) didefinisikan sebagai memiliki kapasitas untuk bangkit dari penderitaan atau kegagalan. Dari transkrip hasil wawancara didapatkan sebanyak 24 pernyataan sikap dan perilaku yang mencerminkan adanya atribut Resiliency pada individu karyawan di ketiga perusahaan televisi swasta nasional yang diteliti. Contoh kata kunci yang menggambarkan sikap dan perilaku tersebut adalah: karyawan tetap bertahan walaupun menerima kritikan yang bersifat personal (transkrip 2 baris 301), secara tim saling 
menguatkan, solid karena sepenanggungan (transkrip 2 baris 303), mampu bertahan terhadap perubahan (transkrip 3 baris 45), sudah sering alami kesulitan sehingga kebal terhadap masalah (transkrip 3 baris 63), semakin semangat berjuang justru saat alami kesulitan, tekanan atau persaingan (transkrip 4 baris 113 dan 127), selalu evaluasi diri, mengalami proses pembelajaran yang mendewasakan diri (transkrip 4 baris 127 dan 155), berjiwa prajurit: dididik secara keras, taat pada aturan, tidak pamrih (baris 177-179, 187 transkrip wawancara ke-4), menyadari bahwa tuntutan yang tinggi akan mengarahkan pada hasil yang juga tinggi (baris 191 transkrip wawancara ke-4), karyawan tertantang untuk berkompetisi karena selalu direndahkan (transkrip 5 baris 232-236 dan 252), kreatif mencari berbagai cara untuk menang di tengah keterbatasan yang ada (transkrip 5 baris 268-269), dan mencoba bertahan walaupun perubahan tidak menyenangkan serta rekan lain banyak yang menyerah (transkrip 5 baris 226-230 dan 304).

Atribut individu yang terakhir dari kategori modal psikologis adalah Optimism. Optimism (realistic and flexible) didefinisikan sebagai memiliki suatu cara yang dapat dijelaskan yang mengkaitkan suatu keadaan positif dengan penyebab yang bersifat internal, permanen dan nyata. Dari transkrip hasil wawancara didapatkan sebanyak 15 pernyataan sikap dan perilaku yang mencerminkan adanya atribut Optimism pada individu karyawan di ketiga perusahaan televisi swasta nasional yang diteliti. Contoh kata kunci yang menggambarkan sikap dan perilaku tersebut adalah: karyawan optimis (transkrip 2 baris 87 dan 89; transkrip 5 baris 184), memandang positif (transkrip 2 baris 155 dan 183), tidak kuatir (transkrip 2 baris 299), fokus pada umpan balik positif dan menerima kritikan secara humor (transkrip 3 baris 301), memiliki energi yang luar biasa (transkrip 3 baris 47), dan menerima tantangan (transkrip 4 baris 191).

Enam atribut individu hasil identifikasi berikutnya dikelompokkan dalam kategori Transformational Leadership Behavior (LEADER), lima atribut mengacu pada konsep teori yang dikemukakan Kouzes dan Posner (1987) dan satu atribut mengacu pada konsep teori Scharmer (2004). Atribut individu yang pertama dari seorang pemimpin transformasional adalah Challenging the Process yaitu memiliki ciri perilaku aktif, memberikan tantangan diantaranya dalam bentuk reorganisasi, bekerja untuk menghasilkan produk baru yang inovatif, dan membuat perubahan atas status quo. Pemimpin transformasional bereksperimen dan berani mengambil resiko, sambil tetap menyadari dan menerima konsekuensi yang mungkin ditimbulkan. Dari transkrip hasil wawancara didapatkan sebanyak 20 pernyataan yang mencerminkan adanya atribut Challenging the Process pada individu pemimpin di ketiga perusahaan televisi swasta nasional yang diteliti. Beberapa kata kunci dari pernyataan narasumber yang menggambarkan sikap dan perilaku tersebut adalah: pemimpin mengkritik atau mempertanyakan efektivitas cara kerja dan cara pikir yang lama (transkrip 2 baris 81, 149, 173, 355, 357), menuntut pelaksana untuk melakukan pengembangan (transkrip 2 baris 359), tidak cukup puas dengan kondisi yang ada saat ini (transkrip 2 baris 363), melakukan studi banding atau benchmarking (transkrip 2 baris 371), membuang semua perilaku lama yang sudah tidak sesuai (transkrip 4 baris 29), membuat pelaksana keluar dari zona nyaman (transkrip 4 baris 103), membiasakan pelaksana untuk argumentatif (transkrip 4 baris 191), menerapkan budaya kritik terhadap karyawan baru (transkrip 4 baris 221), dan 
menantang ide yang dikemukakan pelaksana (transkrip 5 baris 140).

Atribut individu yang kedua dari seorang pemimpin transformasional adalah Inspiring a Shared Vision yaitu memiliki ciri perilaku mencipta dan menginspirasi bawahan untuk bekerja mencapai misi atau sasaran bersama, memiliki pengetahuan yang mendalam tentang kebutuhan dan nilai-nilai yang dianut bawahan, serta memiliki semangat dan keyakinan yang tinggi terhadap visi atau sasaran yang ingin dicapai. Dari transkrip hasil wawancara didapatkan sebanyak 22 pernyataan yang mencerminkan adanya atribut Inspiring a Shared Vision pada individu pemimpin di ketiga perusahaan televisi swasta nasional yang diteliti. Beberapa kata kunci dari pernyataan narasumber yang menggambarkan sikap dan perilaku tersebut adalah: pemimpin memberikan arahan mengenai apa yang harus dicapai (transkrip 2 baris 61), senantiasa menginformasikan perkembangan bisnis yang terbaru (transkrip 2 baris 209), secara jelas mengarahkan perubahan (transkrip 3 baris 17 dan 159), mensosialisasikan perubahan (transkrip 3 baris 37 dan 39), membicarakan bersama, melibatkan dan menarik komitmen pelaksana terhadap perubahan (transkrip 3 baris 127), mendorong pelaksana untuk selalu menghasilkan keunggulan (transkrip 4 baris 63), mengemukakan filosofi perusahaan untuk selalu keluar sebagai nomer satu (transkrip 4 baris 85), pemimpin memiliki visi yang dapat dijelaskan dengan baik (transkrip 5 baris 60).

Atribut individu yang ketiga dari seorang pemimpin transformasional adalah Enabling Others to Act yaitu memiliki ciri perilaku berpikir dengan pendekatan 'kita' atau 'kami', dan bukannya 'saya'. Pemimpin transformasional menyadari bahwa proses pelaksanaan proyek kerja merupakan suatu usaha tim dan pemimpin tidak bisa mencapai keberhasilan seorang diri. Pemimpin transformasional mampu membentuk suatu kerjasama dan memampudayakan bawahan, sehingga menginspirasi mereka untuk menghasilkan kinerja yang lebih baik. Dari transkrip hasil wawancara didapatkan sebanyak 30 pernyataan yang mencerminkan adanya atribut Enabling Others to Act pada individu pemimpin di keempat perusahaan televisi swasta nasional yang diteliti. Beberapa kata kunci dari pernyataan narasumber yang menggambarkan sikap dan perilaku tersebut adalah: pemimpin memberi kesempatan kepada semua orang untuk kemukakan ide atau memberi masukan (transkrip 1 baris 35; transkrip 4 baris 63), menyediakan pelatihan dan pengembangan untuk tim kerja (transkrip 2 baris 47, 147, 157; transkrip 3 baris 47; transkrip 4 baris 123), memberi kepercayaan kepada pelaksana (transkrip 2 baris 103), memberikan kesempatan kepada pelaksana untuk mewakili pemimpin (transkrip 2 baris 107), melibatkan dalam pengambilan keputusan (transkrip 2 baris 123; transkrip 3 baris 41, 119, 125), memampudayakan menjadikan karyawan sebagai think-tank (transkrip 2 baris 149; transkrip 3 baris 143), memberikan kesempatan kepada pelaksana untuk melakukan berdasarkan caranya sendiri (transkrip 3 baris 131), memunculkan tokoh-tokoh dari kalangan pelaksana (transkrip 4 baris 55), mengijinkan terjadinya kesalahan untuk proses pembelajaran (transkrip 4 baris 223).

Atribut individu yang keempat dari seorang pemimpin transformasional adalah Modeling the Way yaitu memiliki ciri perilaku menetapkan standar kinerja yang istimewa dan kemudian memberi contoh bagaimana mencapainya. Pemimpin transformasional menjadi teladan, yaitu tidak hanya mengarahkan tetapi juga melakukan dalam kehidupan kerja sehari-hari dengan tujuan mencapai sasaran dan nilai-nilai yang 
disepakati bersama. Perilaku pemimpin yang menjadi contoh merupakan bentuk perilaku yang paling banyak dikemukakan oleh kelima narasumber yang diwawancara. Dari transkrip hasil wawancara didapatkan sebanyak 67 pernyataan yang mencerminkan adanya atribut Modeling the Way pada individu pemimpin di ketiga perusahaan televisi swasta nasional yang diteliti. Beberapa kata kunci dari pernyataan narasumber yang menggambarkan sikap dan perilaku tersebut adalah: menetapkan target perubahan perilaku dan cara pandang (transkrip 3 baris 21), mempunyai rencana stratejik dengan tahapan dan program yang jelas dalam mencapai visi (transkrip 3 baris 37, 55, 197), mengarahkan dengan jelas (transkrip 2 baris 59, 61, 87, 89; transkrip 3 baris 33, 37, 197, 205, 225; transkrip 5 baris 50), membuat prosedur operasional standar (baris 29 transkrip wawancara ke-4), mengawasi selama proses perubahan diimplementasikan (transkrip 1 baris 62), mengambil tindakan untuk memastikan keberhasilan perubahan (transkrip 1 baris 62), memberi contoh, walk the talk (transkrip 1 baris 68; transkrip 4 baris 51, 179), memiliki komitmen penuh, bahkan sampai mengorbankan waktu pribadi (transkrip 4 baris 53), turun ke lapangan, melepaskan atribut pimpinan saat bertugas di lapangan dan mengarahkan (transkrip 4 baris 55), melakukan evaluasi terhadap pelaksanaan perubahan (transkrip 1 baris 62), menegur tetapi memberi solusi (transkrip 5 baris 140), menerapkan sistem reward and punishment secara tegas (transkrip 4 baris 109, 191, 193; transkrip 5 baris 48).

Atribut individu yang kelima dari seorang pemimpin transformasional adalah Encouraging the Heart yaitu memiliki ciri perilaku mengetahui setiap kontribusi yang diberikan karyawan dan menyediakan penghargaan positif sebagai imbalan atas kontribusi yang telah diberikan. Pemimpin transformasional merayakan setiap pencapaian yang dihasilkan bawahan, baik secara individu, kelompok maupun organisasi dan memastikan bahwa seluruh karyawan terlibat dalam pencapaian tersebut, bukan hanya diri pemimpin itu sendiri. Dari transkrip hasil wawancara didapatkan sebanyak 19 pernyataan yang mencerminkan adanya atribut Encouraging the Heart pada individu pemimpin di ketiga perusahaan televisi swasta nasional yang diteliti. Beberapa kata kunci dari pernyataan narasumber yang menggambarkan sikap dan perilaku tersebut adalah: pemimpin menyapa (transkrip 1 baris 33,37), memberi pujian (transkrip 1 baris 33), memahami tugas dan peran dari masing-masing anak buah (transkrip 1 baris 36), menghargai dengan cara mengenal secara pribadi tiap bawahan (transkrip 1 baris 37), menghargai kinerja dan pengalaman (transkrip 4 baris 29, 45), menciptakan keseimbangan antara hak dan kewajiban (baris 39 transkrip wawancara ke4), menaikkan pangkat bagi pelaksana yang performanya baik (baris 45 transkrip wawancara ke-4), memberikan hak sesuai usaha yang dilakukan (baris 49 transkrip wawancara ke-4), merayakan keberhasilan dengan membagikan bonus bagi seluruh karyawan dan selanjutnya dilakukan secara rutin (baris 69-73,77 transkrip wawancara ke-4), memperhatikan kesejahteraan karyawan (baris 113 transkrip wawancara ke-4), tidak pilih kasih (baris 191 transkrip wawancara ke-4), memberikan imbal jasa atas kinerja dalam bentuk materi yang menyenangkan pelaksana (baris 50, 270 transkrip wawancara ke-5), mewujudkan imbalan sesuai yang dijanjikan (baris 50 transkrip wawancara ke-5), memberikan penghargaan sesuai masa kerja (baris 92 transkrip wawancara ke-5).

Atribut individu yang terakhir dari seorang pemimpin transformasional adalah Presencing yaitu memiliki ciri perilaku 
mampu mengenali dan mewujudnyatakan potensi tertinggi dari seseorang ataupun sekelompok orang, menemukan inner source mereka dan memunculkannya sebagai kapabilitas untuk melakukan inovasi bisnis dan perubahan yang transformasional. Dari transkrip hasil wawancara didapatkan sebanyak 9 pernyataan yang mencerminkan adanya atribut Enabling Others to Act pada individu pemimpin di keempat perusahaan televisi swasta nasional yang diteliti. Beberapa kata kunci dari pernyataan narasumber yang menggambarkan sikap dan perilaku tersebut adalah: pemimpin berhasil menempatkan orang-orang secara tepat pada posisi yang sesuai (baris 103 transkrip wawancara ke-2), yang mampu mewakili si pemimpin (baris 107 transkrip wawancara ke-2) dan mampu mencapai target yang secara sengaja ditetapkan tinggi (baris 143 dan 145 transkrip wawancara ke-2), memahami apa yang harus dilakukan dan mampu mengevaluasi kinerja diri sendiri dan orang lain (baris 149 transkrip wawancara ke-2), serta mampu menciptakan sinergi dengan tim kerja lain (baris 345 transkrip wawancara ke-2). Pemimpin selalu melihat bahwa setiap orang memiliki kelebihan (baris 191 transkrip wawancara ke-4), menantang setiap orang untuk menghasilkan karya sendiri dan terbukti mampu (baris 274 transkrip wawancara ke-5), menuntut karyawan untuk menghasilkan karya terbaik dalam keterbatasan yang sengaja diciptakan (baris 278 transkrip wawancara ke-5).

Dua atribut individu berikutnya masuk dalam kategori Way of Thinking (THINK) mengacu pada konsep teori McShane \& Von Glinow (2007). Individu yang berpikir secara rasional mengambil keputusan berdasarkan fakta serta analisis yang logis dan teratur, dengan tujuan memaksimumkan hasil (McShane \& Von Glinow, 2007; Robbins \& Judge, 2009), umumnya menghindari atau mengabaikan gut instinct pada saat insting tersebut bertentangan dengan informasi yang obyektif dan berperilaku didasarkan atas "reward and punishment" yang mereka dapatkan Scott (2000), serta memilih alternatif yang paling mungkin menghasilkan kepuasan terbesar baginya (Coleman, 1973; Heath 1976; Carling 1992). Dari transkrip hasil wawancara didapatkan sebanyak 21 pernyataan sikap dan perilaku yang mencerminkan atribut Rational Thinking dari individu karyawan pada ketiga perusahaan televisi swasta nasional yang diteliti. Beberapa kata kunci dari pernyataan narasumber yang menggambarkan sikap dan perilaku tersebut adalah: karyawan meminta penjelasan dan menanyakan apa yang diharapkan (transkrip 1 baris 9), mempelajari materi terlebih dulu (transkrip 1 baris 14), memikirkan bagaimana agar inisiatif perubahan diterima, menjelaskan manfaat dari adanya perubahan (transkrip 1 baris 62), sangat rasional (transkrip 2 baris 165-167), menganalisis secara mendalam (transkrip 2 baris 169), menanyakan alasan (transkrip 2 baris 171), menghitung manfaat/untung dan rugi dari diambilnya suatu peluang (transkrip 2 baris 193, transkrip 4 baris 135), mempertanyakan manfaat dari dilakukannya perubahan (transkrip 3 baris 219 3), mengevaluasi program (transkrip 5 baris 114), memilih program yang menguntungkan (transkrip 5 baris 116), memberikan alasan yang logis, beralasan dalam menolak ide (transkrip 5 baris 130, 144, 146, 154-172).

Individu yang memiliki gaya pengambilan keputusan intuitif membuat keputusan berdasarkan inner feelings atau "gut instinct" (McShane \& Von Glinow, 2007). Orang yang berpikir secara intuitif mengandalkan proses tidak sadar yang dihasilkan dari pengalaman yang sudah disarikan (Robbins \& Judge, 2009). Pengalaman yang didapat secara berulang membuat individu dengan cara pikir intuitif 
mampu dengan cepat melihat pola dari suatu situasi, menarik pengalaman lalu yang memiliki asosiasi dengan pola situasi tersebut, dan menetapkan pilihan keputusan dengan segera, walaupun informasi yang tersedia dinilai terbatas. Dari transkrip hasil wawancara didapatkan sebanyak 10 pernyataan sikap dan perilaku yang mencerminkan atribut Intuitive Thinking dari individu karyawan pada ketiga perusahaan televisi swasta nasional yang diteliti. Beberapa kata kunci dari pernyataan narasumber yang menggambarkan sikap dan perilaku tersebut adalah: karyawan memiliki indera keenam dan intuisi yang membuatnya cepat dalam mengambil keputusan (transkrip 2 baris 95), cepat dalam menghitung (transkrip 2 baris 187), cepat dalam menyampaikan pemikiran dan terbukti berhasil (transkrip 2 baris 191), intuitif (transkrip 3 baris 181,189), pengalaman dan kematangan (transkrip 3 baris 191), memiliki sense yang tinggi (transkrip 4 baris 117), intuisi yang tajam tidak hanya saat melakukan peramalan tetapi juga saat membuat keputusan (transkrip 4 baris 119), intuisi yang tajam karena jam terbang atau pengalaman (transkrip 4 baris 123), memiliki rasa (feeling) yang baik terkait bisnis yang dijalankan (transkrip 5 baris 106).

Tiga atribut individu yang terakhir dikelompokkan dalam kategori Organizational Commitment (COMMIT) menurut teori yang dikemukakan oleh Allen \& Meyer (1996). Atribut individu yang pertama dari kategori Komitmen terhadap Organisasi adalah Affective Commitment, yaitu komitmen terhadap organisasi yang lahir karena adanya perasaan terikat secara emosi pada suatu organisasi dan memiliki suatu keyakinan atas nilai-nilai yang dianut organisasi tersebut. Dari transkrip hasil wawancara didapatkan sebanyak 36 pernyataan sikap dan perilaku yang mencerminkan adanya atribut Afective
Commitment pada individu karyawan di ketiga perusahaan televisi swasta nasional yang diteliti. Beberapa kata kunci dari pernyataan narasumber yang menggambarkan sikap dan perilaku tersebut adalah: karyawan mandiri, inisiatif dan bertanggungjawab atas tugas/peran (transkrip 1 baris 35,58,66), setia dan rela berkorban untuk organisasi (transkrip 1 baris 58; transkrip 4 baris 53), komitmen atas kesepakatan atau janji yang telah dibuat (transkrip 1 baris 58, 66), menyelesaikan tugas dengan sungguh-sungguh dan semaksimal mungkin (transkrip 1 baris 58), tidak pamrih, tugas adalah pengabdian (transkrip 1 baris transkrip 58; transkrip 4 baris 187, 193), tidak ada kepentingan pribadi, semata untuk kepentingan organisasi (transkrip 2 baris 131,337), menyukai tantangan (transkrip 2 baris 341), adanya kebersamaan, kekeluargaan, menyatu (transkrip 3 baris 33,57,63; transkrip 4 baris 49, 55, 198-200), passion atau gairah untuk berubah (transkrip 3 baris 75), dipercaya melakukan menurut cara sendiri (transkrip 3 baris 131), dilibatkan sehingga memahami persoalan (transkrip 3 baris 133), bangga bisa membesarkan perusahaan (transkrip 4 baris 191), memiliki passion atas profesi yang dijalankan (transkrip 4 baris 302), menikmati dan menyukai pekerjaan (transkrip 2 baris 265, 267, 283; transkrip 5 baris 190-196, 218-222, 304).

Atribut individu yang kedua dari kategori Komitmen terhadap organisasi adalah Normative Commitment. Normative Commitment lahir karena adanya perasaan terikat untuk memenuhi kewajiban dengan alasan moral dan etika. Dari transkrip hasil wawancara didapatkan sebanyak 14 pernyataan sikap dan perilaku yang mencerminkan adanya atribut Normative Commitment pada individu karyawan di ketiga perusahaan televisi swasta nasional yang diteliti. Beberapa kata kunci dari 
pernyataan narasumber yang menggambarkan sikap dan perilaku tersebut adalah: karyawan merasa sudah seharusnya mengikuti perubahan karena jaman sudah berbeda (baris 47 transkrip wawancara ke-3), harus semangat melakukan perubahan (baris 47 transkrip wawancara ke-3), menghargai manajemen yang tidak terapkan tindakan yang merugikan karyawan (baris 49 transkrip wawancara ke-3), diperlakukan manusiawi (baris 53 transkrip wawancara ke-3), diajak membicarakan masalah (baris 53 transkrip wawancara ke-3), memberikan usaha dalam bekerja karena perusahaan sudah memberikan imbalan (baris 49 transkrip wawancara ke-4), melihat ada pimpinan yang lama yang masih menduduki posisi puncak pada organisasi yang baru (baris 36 transkrip wawancara ke-53), diminta oleh pimpinan yang baru untuk bangkitkan semangat rekan-rekan yang lain (baris 36 transkrip wawancara ke-5), pimpinan yang baru sudah dikenal dan dinilai memiliki visi yang jelas (baris 60 transkrip wawancara ke5).

Atribut individu yang ketiga dari kategori Komitmen terhadap organisasi adalah Continuance Commitment yaitu komitmen terhadap organisasi yang lahir karena adanya perasaan terikat karena tahu bahwa secara ekonomis biaya yang akan dikeluarkan bila keluar dari organisasi akan sangat tinggi atau masalah yang akan dihadapi bila berpindah ke organisasi lain akan jauh lebih banyak. Dari transkrip hasil wawancara didapatkan sebanyak 22 pernyataan sikap dan perilaku yang mencerminkan adanya atribut Continuance Comitment pada individu karyawan di ketiga perusahaan televisi swasta nasional yang diteliti. Beberapa kata kunci dari pernyataan narasumber yang menggambarkan sikap dan perilaku tersebut adalah: mengikuti perubahan dengan terpaksa karena usia sudah tua (baris 75 transkrip wawancara ke-
2), sangat memperhatikan besaran imbal jasa yang akan diterima (baris 239,241,245 transkrip wawancara ke-2; baris 81,83 transkrip wawancara ke-3), mementingkan karir/posisi (baris 81 transkrip wawancara ke-3 baris 95,109 transkrip wawancara ke4;baris 36 transkrip wawancara ke-5), bekerja dengan baik karena takut imbalan yang didapat berkurang (baris 50 transkrip wawancara ke-5), harus memenuhi kebutuhan keluarga dan kepentingan pribadi (baris 109 transkrip wawancara ke-4; baris 74, 86 transkrip wawancara ke-5), tidak ada pilihan lain yang lebih baik (baris 88 transkrip wawancara ke-5).

\section{SIMPULAN DAN SARAN}

Tujuan penelitian yang pertama terpenuhi dengan ditemukannya lima belas atribut individu pada tiga perusahaan televisi di Indonesia yang terkait dengan keberhasilan perusahaan mengimplementasikan perubahan transformasional korporat. Terkait dengan tujuan penelitian yang kedua, hasil penelitian ini mengkonfirmasi sebagian dari teori yang dibangun berdasarkan temuan penelitian sebelumnya di negara barat yang menyebutkan efficacy dan leadership sebagai anteseden langsung dari kesiapan berubah. Pada penelitian ini, secara kualitatif efficacy dan beberapa aspek dari transformational leadership behavior yang terdiri dari challenging the process, inspiring shared vision, enabling others to act, modeling the way, encouraging the heart dan presencing ditemukan merupakan atribut individu yang dimiliki karyawan pada tiga perusahaan televisi swasta nasional di Indonesia yang menjadi obyek studi. Selain itu juga ditemukan atribut individu lainnya yaitu hope, resiliency, optimism, rational dan intuitive thinking, serta affective, normative dan continuans commitment. 
Tujuan penelitian yang ketiga dapat dijawab melalui hasil identifikasi yang ditunjukkan pada Gambar 2. Dari gambar terlihat bahwa tidak semua atribut individu muncul atau dikemukakan di semua organisasi yang menjadi obyek studi. Atribut individu Encouraging The Heart tidak muncul dikemukakan oleh kedua narasumber di TV A. Atribut individu yang muncul dikemukakan oleh kelima narasumber adalah
Efficacy, Resiliency, Optimism, Inspiring a Shared Vision, Enabling Others to Act, Modeling The Way, Rational Thinking dan Affective Commitment. Atribut individu Modeling the Way adalah atribut yang paling sering dikemukakan oleh seluruh narasumber (76 kutipan), diikuti Affective Commitment (36 kutipan), Enabling Others to Act (30 kutipan) dan Resiliency (24 kutipan).

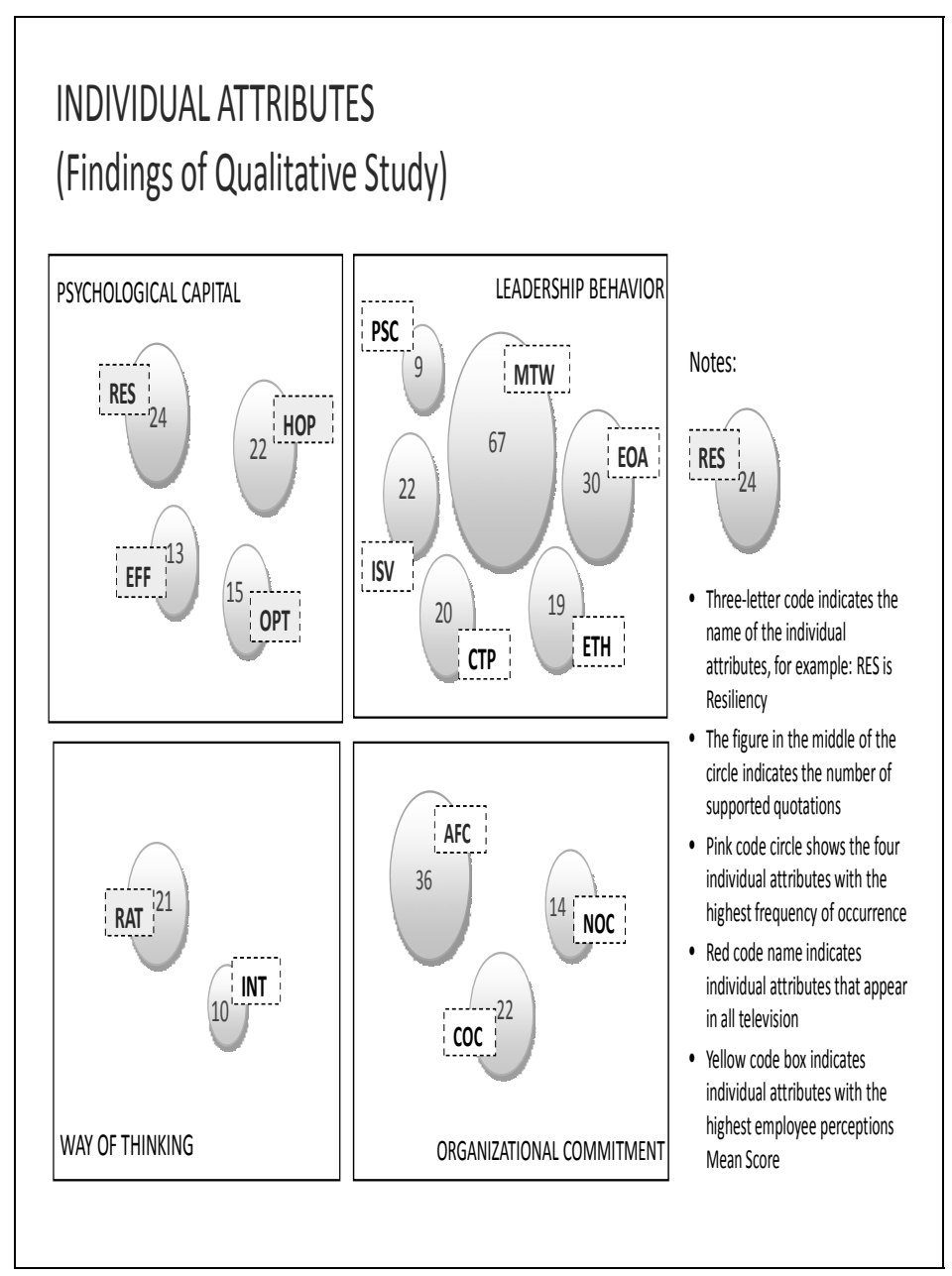

Gambar 2.

Atribut Individu Hasil Identifikasi pada Tiga Perusahaan Televisi di Indonesia Yang Mengalami Perubahan Transformasional di Tingkat Korporat. 
Berdasarkan jawaban terhadap tujuan penelitian yang pertama hingga ketiga, dibuatlah rancangan model struktural penelitian yang menjawab tujuan penelitian keempat. Rancangan model struktural penelitian yang ditunjukkan pada Gambar 3. memuat lima variabel laten tingkat dua dan 18 variabel laten tingkat satu.

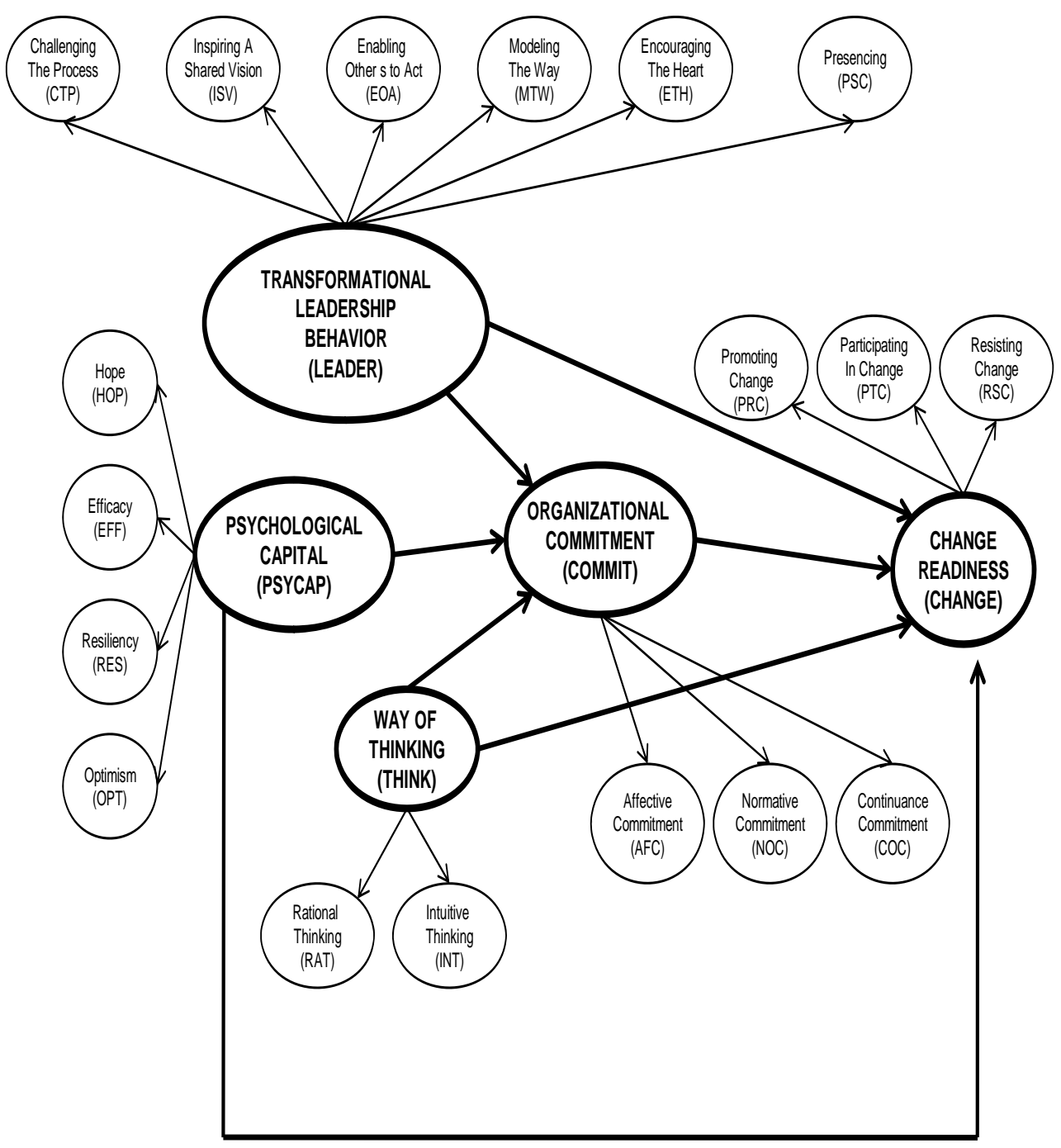

Gambar 3.

Rancangan Model Penelitian Hubungan Atribut Individu dan Kesiapan Berubah pada Perusahaan Televisi di Indonesia yang Mengalami Perubahan Transformasional Korporat. 
Penelitian ini memiliki beberapa keterbatasan, diantaranya: dikarenakan penelitian dilakukan tidak pada saat inisiatif perubahan diimplementasikan, kemungkinan ada perasaan atau perilaku yang tidak teridentifikasi atau bahkan sudah termodifikasi karena pengaruh waktu atau proses. Adanya informasi tidak langsung (narasumber menceritakan ulang peristiwa lampau) yang mungkin sudah mengalami penyaringan atau evaluasi berdasarkan pandangan dari narasumber. Tidak semua narasumber memiliki kemampuan yang sama dalam hal artikulasi dan penyampaian pandangan. Selain itu, pada tahap studi kualitatif tidak berhasil dilakukan wawancara terhadap pelaku perubahan secara lengkap untuk dua peran yang ada (pemimpin dan pelaksana perubahan) di masing-masing perusahaan televisi yang menjadi obyek studi. Sehingga kemungkinan ada fenomena atau persepsi dari peran yang berbeda yang tidak tertangkap. Untuk penelitian dengan tujuan serupa, sebaiknya dilakukan penelitian yang bersifat longitudinal study dengan metode pengamatan langsung pada organisasi yang merencanakan akan mengimplementasikan suatu inisiatif perubahan.

Untuk generalisasi temuan, perlu dilakukan penelitian lebih lanjut atau studi konfirmasi, untuk melihat secara kuantitatif bagaimana hubungan dari atribut individu yang berhasil diidentifikasi dengan kesiapan berubah. Atribut individu mana yang secara signifikan memiliki hubungan positif dengan kesiapan berubah. Apakah hubungan antara atribut individu tersebut dengan kesiapan berubah bersifat langsung atau tidak langsung. 


\section{DAFTAR PUSTAKA}

Allen NJ, Meyer JP. 1996. “Affective, continuance, and normative commitment to the organization. An examination of construct validity”. Journal of Vocational Behavior. 49.

Ansoff HI, McDonnell EJ. 1990. Implanting Strategic Management. Prentice-Hall Ltd.

Armenakis AA, Harris SG, Mossholder KW. 1993. "Creating Readiness for Organizational Change”. Human Relations, Vol 46 No 6 pp 681-703.

Carling A. 1992. Social Divisions. Verso.

Coleman J. 1973. The Mathematics of Collective Action. Heinemann.

Cooper DR, Schindler PS. 2008. Business Research Methods. McGraw-Hill International.

Cunningham CE, Woodward, Shannon, MacIntosh. 2002. "Readiness for Organizational Change: A Longitudinal Study of Workplace, Psychological and Behavioral Correlates”. Journal of Occupational and Organizational Psychology, Vol 75 pp 377-392.

Eby LT, Adams DM, Russell JEA, Gaby SH. 2000. "Perceptions of Organizational Readiness for Change: Factors Related to Employee's Reactions to The Implementation of Team-based Selling”. Human Relations Vol 53 No 3 pp 419-442.

Goulding, C. 2002. Grounded Theory. Sage Publication.

Grieve B. 2005. Leadership Communication: A Key Success Factor in Organizational Readiness for Change. Royal Roads University.

Hanpachern C, Morgan GA, Griego OV. 1998. „An Extension of the Theory of Margin: A Framework for Assessing Readiness for Change”. Human Resource Development Quarterly Vol. 9 No. 4 pp. 339350.

Heath A. 1976. Rational Choice and Social Exchange. Cambridge (UK): Cambridge Univ Pr.

Holt DT, Armenakis AA, Feild HS, Harris SG. 2007. "Readiness for Organizational Change, The Systematic Development of Scale”. The Journal of Applied Behavioral Science Vol. 43 No. 2 pp. 232-255.

INDOCOMMERCIAL. 2011. Laporan Bisnis No 427. Capricorn Indonesia Consult Inc.

Kouzes JM \& Posner BZ. 1987. “Development and Validation of the Leadership Practices Inventory”. Educational and Psychological Measurement, Vol. 48 pp 483-496.

Louise, R. 2004. The Meaning of Home Care and Caring for Aging Relatives at Home, The Haitian Canadian Primary Caregivers Perspectives. Disertasi. School of Nursing. The University of British Columbia.

Luthans F. 2010. Psychological Capital, Secrets to Boost Productivity \& Win The Competition. One Day Executive Class. Markplus Inc.

Madsen SR, John CR, Miller D. 2006. “Influential Factors in Individual Readiness for Change”. Journal of Business and Management Vol. 12 No. 2 pg. 93.

McShane SL, Von Glinow MA. 2007. Organizational Behavior. McGraw-Hill Irwin.

Mulya A dan Indonesian People Champions. 2011. Grow with Character, Champion Stories. Gramedia Pustaka Utama.

Palmer I, Dunford R, Akin G. 2009. Managing Organizational Change. McGraw-Hill International Edition.

Rafferty AE, Simons RH. 2006. "An Examination of the Antecedents of Readiness for Fine-Tuning and Corporate Transformation Change”. Journal of Business and Psychology Vol 20 No 3 pg 325

Rahayu EM. 2010. “Menyulap Yang Lesu Jadi Happening”. Majalah SWA No. 24/XXVI.

Scharbo-DeHann, M. 1993. The Experience of Menopause, A Feminist Interpretation Study, Disertasi. School of Nursing. Georgia University.

Scharmer CO. 2004. Addressing the Blind Spot of Our Time. An Executive Summary of The New Book by Otto Scharmer Theory U: Leading from The Future as It Emerges. www. theoryU.com.

Scott J. 2000. Understanding Contemporary Society: Theories of The Present. London (UK): Sage.

Self DR, Schraeder M. 2009. "Enhancing the Success of Organizational Change”. Leadership \& Organization Development Journal Vol. 30 No. 2 pp. 167-182. 
Perancangan Model Struktural ... (Eva Hotnaidah Saragih)

Smith I. 2005. “Achieving Readiness for Organizational Change”. Library Management Vol 26 No 6/7 pg 408.

Weick KE. 1995. Sensemaking in Organizations. Sage Publications. 